\title{
The molecular epidemiology of rotavirus strains causing gastroenteritis in infant in the region of Mid Iraq
}

\author{
W. S. Abood \\ Coll.of Med./ Unive. of \\ Al- Qadisiya
}

\author{
S. A. Al-Juboury \\ Coll. of Med./ Unive. of \\ Kufa
}

\author{
M. A. Al-Rodhan \\ Coll. of Vet. Med./ Unive. \\ of Al- Qadisiya
}

\begin{abstract}
Rotavirus diarrhea is a leading cause of child death. It is a major concern in developing and developed countries. In Iraq, few studies and analysis were executed for genetic assessment of rotavirus.The aim of this study was to estimate the prevalence of rotavirus caused gastroenteritis and identify the distribution of the circulating $G$ and $P$ types of rotavirus among infants admitted to the hospital or treated as outpatients in three governorates in the region of Mid-Iraq for symptoms of gastroenteritis. This study was undertaken during the period from June 2010 to April 2012 in infants under 1 year suffering from acute gastroenteritis. Group A rotaviruses were detected in stools by latex agglutination test and genotyped using semi nested multiplex reverse transcription PCRs with type-specific primers on the basis of their outer capsid proteins.Of the 348 stool specimens from infants with acute gastroenteritis, $42.45 \%$ were positive for rotavirus A. The predominant G type was G1 (48.57\%), followed by G2 (22.14\%), G9 (11.42\%), G3 (2.14\%), G4 (0.71\%). Only P [8] (61.4\%), P [4] (11.4\%) and P [6] (5.7\%) genotypes were found. Infants of 9 and 10 months of age were most frequently affected. The prevalence of rotavirus infection peaked in the Autumn season, when temperatures were low, and decreased in summer. Epidemiological knowledge of rotavirus is critical for the development of effective preventive measures, including vaccines. These data will help to make informed decisions as to whether rotavirus vaccine should be considered for inclusion in Iraqi National Immunization Program.
\end{abstract}

\section{Introduction}

Rotavirus is the single most important cause of severe gastroenteritis in young children throughout the world. Globally, an estimated 702,000 children die each year due to rotavirus diarrhea [1]. This large impact of rotavirus disease has speeded the development of rotavirus vaccines. Therefore, determining the prevalence and types of rotaviruses within regions is essential to prepare for introducing a vaccine [1].They are members of the Reoviridae family and contain a genome consisting of 11 segments of double stranded RNA (dsRNA) enclosed in a triple layered capsid [2]. The outer layer of rotaviruses is composed of two proteins, VP7 and VP4, encoded by RNA segments 9 and 4, respectively. Those proteins elicit neutralizing antibody responses and form the basis of the current classification of group A rotaviruses into G (VP7) and P (VP4) types, where $G$ stands for glycoprotein and $P$ for protease sensitive protein [3]. Currently, 27
$\mathrm{G}$ genotypes and $35 \mathrm{P}$ genotypes have been reported in humans and animals [4]. A dual typing system is necessary in order to characterize the strains of rotavirus cocirculating during different rotavirus seasons in different locations [5]. Globally, P[8], $\mathrm{P}[4]$ and $\mathrm{G} 1$ to $\mathrm{G} 4$ and G9 are the most common P- and G-types in humans. Nevertheless, other $G$ and $P$ types have been found to be highly prevalent in different areas of the world (e.g. G5 types in Brazil, G10 types in India) [6,7], and more recently, the combinations G12P[8] and G12P[6] have been reported [8].In Iraq, the death rate in children $<5$ years of age was reported to be 130/1,000 for boys and 120/1,000 for girls in 2003 [9]. Diarrhea is a major cause of illness and death in Iraqi children; however, little information exists about the origin of childhood diarrhea. A study showed that rotavirus accounted for $24 \%$ of acute diarrhea in hospitalized children in Basrah [10]. In Iraqi Kurdistan, a study revealed that 
$\begin{array}{llll}\text { AL-Qadisiya Journal of Vet.Med.Sci. } \quad \text { Vol./12 } & \text { No./1 }\end{array}$

$37 \%$ of investigated children with gastroenteritis were infected with rotavirus [11]. A third study stated that $51.98 \%$ of diarrheal children showed positive results for rotavirus antigen in Najaf governorate [12].

\section{Materials and methods}

Study population: Three hundred eighty four stool specimens from infants suspected to have viral diarrhea were involved in the present study. Their ages were below one year of age. Among them one hundred seventy two infants were admitted to Maternity and Child Teaching Hospital in three governorates (Addiwaiya, Najaf and Babylon) and two hundred fourteen infants from the attendants of outpatient departments of the hospitals, some primary health care centers and some private clinics. The exclusion criteria were: Age more than one year, symptoms for more than three days, diarrhea with blood and mucus and hospital acquired diarrhea. The period of specimen collection extended from June 2010 to April 2012. A case of diarrhea was defined with the following criteria:

1. The presence of three or more liquid evacuations per day.

2. Loss of the usual pattern of daily evacuation.

3. A change in the consistency of the evacuation from solid or semi-solid to liquid, accompanied or not by vomiting, fever and dehydration.

Infants with nosocomial or chronic diarrhea were excluded from the study.The stool samples were routinely screened for the presence of VP6 group A rotavirus antigen by latex agglutination test using a commercial kit (Biotec ${ }^{\circledR}$ UK). All rotavirus-positive samples were confirmed by RT-PCR and genetically characterized. The viral RNA was extracted from 20\% stool suspensions in phosphate-buffered saline using the Accuzol $^{\mathrm{TM}}$. Bioneer, Korea), according to the manufacturer's instructions. Rotavirus $\mathrm{G}$ and $\mathrm{P}$ genotyping was performed using semi-nested type specific multiplex RT-PCR that could detect seven G-types and six P-types. Briefly, in order to identify the $G$ type, an 881 nucleotide fragment of the VP7 region was amplified with generic primers VP7F and VP7R [14]. The $G$ genotypes were subsequently determined on amplicons obtained using a pool of internal primers specific for G1-G4 and G8-G10 rotavirus genotypes in combination with the appropriate reverse consensus primers [14]. Similarly, a 663 nucleotide fragment of the VP4 region was reverse transcribed and amplified using the generic primers VP4F and VP4R, and $\mathrm{P}$ genotyping was done using internal primers specific for $\mathrm{P}[4], \mathrm{P}[6], \mathrm{P}[8]$, $\mathrm{P}[9], \mathrm{P}[10]$ and $\mathrm{P}[11]$ [15]. All the RT-PCRs were performed with viral RNA extracted from reference samples as positive controls and RNase free water as negative control. RT-PCR fragments were electrophoresed in $2 \%$ agarose gels in Trisborate- EDTA buffer along with a 2000-bp DNA ladder(Bioneer) . The gels were stained with ethidium bromide and amplicons were viewed with UV light.

\section{Results}

Of the 348 fecal specimens analyzed, 163 tested positive for rotavirus by latex agglutination test. Table (1) is illustrating the distribution of the diagnosed infants to have rotaviral gastroenteritis were little difference is found and male babies constitute $43.9 \%$ of the cases while female infants were $40.5 \%$. This slight difference may be attributed to the fact that in rural area male infants are privileged to a certain degree over females and receive more care from the parents. Otherwise, there is no facts improved that males are more susceptible for rotavirus infection than females. 

AL-Qadisiya Journal of Vet.Med.Sci.
Vol./12
No./1
2013

Table(1). Distribution of positive and negative rotavirus LAT for diarrheic infants according to

\begin{tabular}{|l|l|l|l|}
\hline Sex & Total cases & $\begin{array}{l}\text { Rotavirus } \\
+v e\end{array}$ & Percentage \\
\hline Male & 221 & 97 & $43.9 \%$ \\
\hline Female & 163 & 66 & $40.5 \%$ \\
\hline Total & 384 & 163 & $42.2 \%$ \\
\hline
\end{tabular}

Distribution of LAT positive cases according to the governorates

The following table (table 2) is illustrating the distribution of positive diarrheal cases for rotavirus according to LAT test in the mid Euphrates territories in the three governorates from which specimens collected.

The distribution of LAT positive cases among governorates was $40 \%, 51.6 \%$ and $44 \%$ for Addiwaniya, Najaf and Babylon respectively.

Table (2). Distribution of rotavirus LAT positive specimens according to governorates.

\begin{tabular}{|l|l|l|l|}
\hline Source & $\begin{array}{l}\text { Number of } \\
\text { tested } \\
\text { specimens }\end{array}$ & $\begin{array}{l}\text { Number of } \\
\text { positive }\end{array}$ & $\begin{array}{l}\text { Percentage } \\
\text { of positive } \\
\%\end{array}$ \\
\hline Addiwaniya & 205 & 82 & 40 \\
\hline Najaf & 91 & 47 & 51.6 \\
\hline Babylon & 88 & 34 & 44 \\
\hline Total & 384 & 163 & 42.45 \\
\hline
\end{tabular}

\section{Distribution of LAT positive cases according to age groups}

In this study, rotavirus was detected in the stool of $42.45 \%(163 / 384)$ of patients studied. The highest percentage of the cases occurred in children at 9 and 10 months old (Table 3), which is the susceptible expected target age group. In slightly older children, rotavirus infection can be asymptomatic, probably because they have some degree of protection from clinical disease owing to previous infection with this agent. While in the younger groups a probable protection may come from mother milk or transplacental immunity.

Table (3). Distribution of rotavirus LAT positive and negative cases in children less than one year old with diarrhea according to age groups.

\begin{tabular}{|l|l|l|l|l|l|}
\hline $\begin{array}{l}\text { Age } \\
(\text { months })\end{array}$ & $\begin{array}{l}\text { Total } \\
\text { cases } \\
\text { No. }\end{array}$ & \multicolumn{2}{|c|}{$\begin{array}{c}\text { Rotavirus +ve } \\
\text { No. }\end{array}$} & \multicolumn{2}{c|}{$\begin{array}{c}\text { Rotavirus }- \text { ve } \\
\text { No. }\end{array}$} \\
\hline $1+2$ & 46 & 15 & 32.6 & 31 & 67.3 \\
\hline $3+4$ & 58 & 23 & 39.6 & 35 & 60.4 \\
\hline $5+6$ & 57 & 20 & 35 & 37 & 65 \\
\hline $7+8$ & 81 & 40 & 49.3 & 41 & 50.7 \\
\hline $9+10$ & 68 & 35 & 51.4 & 33 & 48.6 \\
\hline $11+12$ & 74 & 30 & 40.5 & 44 & 59.5 \\
\hline Total & 384 & 163 & 41.4 & 221 & 58.6 \\
\hline
\end{tabular}




\section{$\begin{array}{llll}\text { AL-Qadisiya Journal of Vet.Med.Sci. } & \text { Vol./12 } & \text { No./1 }\end{array}$}

Rotavirus infection has been observed to follow a seasonal pattern in different regions, in this study it was found that it is associated with the more temperate climate at a drier atmosphere. The seasonal distribution of this infection during Autumn months (September and October) was higher than other months of the year.Of the 163 specimens tested positive for rotavirus antigen by latex agglutination test, 140 specimens were submitted to amplification by RT-PCR. A second amplification for $G$ and $\mathrm{P}$ typing was done separately.

G typing
Nested multiplex PCR was performed in which the first round amplified the whole of the VP7 region (1062 bp). This produced positive results in samples. The second round was type-specific and sought both the usual types (G1, G2, G3, and G4) and the emergent $G$ type (G9). Results, (Table 4) show that G1 was the most common genotype detected (68/140,48.57\%), followed by the $\mathrm{G} 2(31 / 140,22.14 \%)$. G9 was found in 16 specimen $(16 / 140,11.42 \%)$. The other genotypes found, G3and G4, were much less common at $2.14 \%(3 / 140)$ and $0.71 \%$ (1/ 140), respectively. 21/140 were not determined by $\mathrm{G}$ typing.

Table (4). Frequency of HRV G types as determined by RT-PCR

\begin{tabular}{|l|l|l|l|}
\hline G type & Number & Percentage\% & Primer used \\
\hline G1 & 68 & 48.57 & aBT1 \\
\hline G2 & 31 & 22.14 & aCT2 \\
\hline G3 & 3 & 2.14 & G3-Aust \\
\hline G4 & 1 & 0.71 & aDT4 \\
\hline G9 & 16 & 11.42 & mG9 \\
\hline N.D & 21 & & \\
\hline
\end{tabular}

\section{P typing}

Nested multiplex PCR was performed in which the first round amplified the whole of the VP4 region (867 bp). This produced positive results in samples. The second round was type-specific and investigated the $\mathrm{P}$ genotypes $\mathrm{P}[8], \mathrm{P}[6], \mathrm{P}[4]$ and $\mathrm{P}[10]$ using $\mathrm{P}$ specific primers $1 \mathrm{~T}-1,3 \mathrm{~T}-1$ 2T-1, 4T-1 and $\% \mathrm{~T}-1$ as a pool of primers against Beg9 as a common primer for the VP4 gene. A total of $86(61.4 \%)$ were $\mathrm{P}[8], 8(5.7 \%)$ were $\mathrm{P}[6]$, and $16(11.4 \%)$ were $\mathrm{P}[4]$. and 30 $(21.4 \%)$ were $\mathrm{P}$ nontypeable. None of the rotaviruses was both $\mathrm{G}$ and $\mathrm{P}$ non typeable(table5).

Table (5) Frequency of human rotavirus $\mathrm{P}$ types in infants with diarrhea according to RT-PCR typing.

\begin{tabular}{|c|l|l|l|}
\hline P type & Number & Percentage\% & Primer \\
\hline $\mathrm{P}[8\}$ & 86 & 61.4 & $1 \mathrm{~T}-1$ \\
\hline $\mathrm{P}[6]$ & 8 & 5.7 & $3 \mathrm{~T}-1$ \\
\hline $\mathrm{P}[4]$ & 16 & 11.4 & $2 \mathrm{~T}-1$ \\
\hline N.D. & 21.4 & & \\
\hline
\end{tabular}

\section{Discussion}

The present study described the epidemiology of rotavirus infections in hospitalized and non-hospitalized children and infants in various cities of the region of Middle of Iraq between April 2010 and June 2012. Rotavirus is the most common cause 
of non-bacterial gastroenteritis in children, not only in developing countries but also in developed countries. A total of 384 fecal specimens were tested for rotavirus and $42.45 \%$ were positive. These results are lower than previous findings on rotavirus prevalence in Mid Iraq (51.98\%) [12]. More consistent proportion (37\%) of rotavirus gastroenteritis were found in different study in Iraqi Kurdistan. Arab countries like Saudi Arabia [16] and Egypt [17], but this is lower than the prevalence of rotavirus attained in Syria (61\%) [18], Oman (50\%) [19] and Kuwait (44\%) [20]. These different detection rates may be explained by different conditions of the studies, such as the season of sampling and the sampling methods. For example, in other studies samples were collected only from hospitalized children, whereas in our study, they were collected from inpatients and outpatients, which may have affected the prevalence rates. Rotavirus was detected continuously throughout the years of study, with peak prevalence occurring in September and October. In Iraq, this is the first study to determine the seasonal distribution of rotavirus infection.
The change in the temporal distribution of rotavirus cases can be explained by the variability of mean temperature, relative humidity, and rainfall. A number of Arab and Middle East countries including Iran [21], Libya [22], Morocco [23], Oman [24], and Saudi Arabia [16] reported that the peak season for rotavirus gastroenteritis was in the winter from November to April. The exception to this is Egypt, where rotavirus infections peak from July to November [25]. One of the main goals of this study was to characterize the VP7 (G genotype) and VP4 ( $\mathrm{P}$ genotype) gene segments of the Iraqi rotavirus strain. It has to be mentioned that this study dealt with strains isolated from only three cities in Iraq (in the region of Mid Iraq) and surveillance was limited to a period of about 2 years. It will be important to continue surveillance and the characterization of rotavirus strains in Iraq in order to monitor changes over time. It is equally important to initiate studies in other regions of Iraq in order to have a comprehensive picture of strain distribution in the country.

\section{Conclusions}

In conclusion, the present study confirms the current burden of rotavirus gastroenteritis in younger children, especially small infants, and highlights the diversity of rotavirus strains circulating in Iraq and neighboring areas. Continuous prospective monitoring of circulating strains of rotavirus is desirable to detect any changes in their distribution promptly and to assess the effectiveness of active immunization programs. Future studies are needed in which systematic surveillance of gastroenteritis is done for long periods of time with consistent methods in order to find explanations for the apparent emergence of rotavirus variants in populations.

\section{References}

1. Parashar UD, Burton A, Lanata C, et al.Global mortality associated with rotavirus disease among children in 2004. J Infect Dis;2009. 200(November (Suppl. 1)):S9-15.

2. Estes MK: Rotaviruses and their replication. In Fields Virology..3rd edition. Edited by: Fields BN, et al. Lippincott Raven, Philadelphia, PA; 1996:1625-1655.
3. Hassine-Zaafrane et al. BMC Infectious Diseases 2011, 11:266 http://www.biomedcentral.com/147 1-2334/11/266 Page 5 of 6

4. Estes MK, Cohen J: Rotavirus gene structure and functions. Microbiol Rev 1989, 53:410-449.

5. Matthijnssens J, Ciarlet M, McDonald SM, Attoui H, Bányai K, Brister JR, Buesa J, Esona MD, Estes MK, Gentsch JR: Uniformity of rotavirus 
strainnomenclature proposed by the Rotavirus Classification Working Group (RCWG). Arch Virol 2011.

6. Gentsch JR, Woods PA, Ramachandran M, Das BK, Leite JP, Alfieri A, Kumar R, Bhan MK, Glass RI: Review of $\mathrm{G}$ and $\mathrm{P}$ typing results from a global collection of rotavirus strains: implications for vaccine development. J Infect Dis 1996, 174(Suppl 1):S30-S36.

7. Ramachandran M, Das BK, Vij A, Kumar R, Bhambal SS, Kesary N: Unusual diversity of human rotavirus $\mathrm{G}$ and $\mathrm{P}$ genotypes in India. $\mathrm{J}$ Clin Microbiol 1996, 34:436-439.

8. Ahmed K, Batuwanthudawe R, Chandrasena TG, Mitui MT, Rajindrajith S, Galagoda G, Pun SB, Uchida R, Kunii O, Moji K, Abeysinghe $\mathrm{N}$, Nishizono A, Nakagomi O: Rotavirus infections with multiple emerging genotypes in Sri Lanka. Arch Virol 2010, 155:71-75.

9. World Health Organization-Iraq. Statistics by country or region. 2003 [cited 2005 Oct 19]. Available from http://www3.who.int/whosis/ country/indicators. cfm?country= IRQ \& language $=$ English .

10. Mahmood DA, Feachem RG. Clinical and epidemiological characteristics of rotavirus- and EPEC-associated hospitalized infantile diarrhea in Basrah, Iraq. J Trop Pediatr. 1987;33:319-25.

11. Herish M. Ahmed, J. Brian S. Coulter, Osamu Nakagomi, C. A. Hart, Jamal M. Zaki, Abas A. Al-Rabaty, Winifred Dove, and Nigel A. Cunliffe Molecular Characterization of Rotavirus Gastroenteritis Strains,Iraqi Kurdistan. Emerging Infectious Diseases • www.cdc.gov/eid • Vol. 12, No. 5, May 2006
12. Khalida K. A. Al-Kelaby. Study on rotavirus serovars $\mathrm{G} 1$ and $\mathrm{G} 2$ isolated from acute diarrhea of children. Ph.d thesis, Babylon University. 2008.

13. Hassine-Zaafrane et al. BMC Infectious Diseases 2011, 11:266 http://www.biomedcentral.com/147 1-2334/11/266 Page 2 of 6.

14. Iturriza-Gómara $\mathrm{M}$, Kang $\mathrm{G}$, Gray $\mathrm{J}$ : Rotavirus genotyping: keeping up with an evolving population of human rotaviruses. J Clin Virol 2004,31:259-265

15. Simmonds MK, Armah G, Asmah R, Banerjee I, Damanka S, Esona M, Gentsch JR, Gray JJ, Kirkwood C, Page N, Iturriza-Gómara M: New oligonucleotide primers for $\mathrm{P}$ typing of rotavirus strains: Strategies for typing previously untypeable strains. J Clin Virol 2008, 42:368-373.

16. Kheyami AM, Areeshi MY, Dove W, Nakagomi O, Cunliffe NA, Anthony HC: Characterization of rotavirus strains detected among children and adults with acute gastroenteritis in Gizan, Saudi Arabia. Saudi Med J 2008, 29(1):90-93.

17. Kamel AH, Ali MA, El Nady HG, de Rougemont A, Pothier P, Belliot G: Predominance and circulation of enteric viruses in the region of Greater Cairo, Egypt. J Clin Microbiol 2009, 47(4):1037-1045.

18. Teleb N: Rotavirus Surveillance Network in the Eastern Mediterranean regional. Presented at the 8th International Rotavirus Symposium 2008, June 3-4 Istanbul; 2008.

19. Al Awaidy SA, Bawikar S, Al Busaidy S, Baqiani S, Al Abedani I, Varghesem R: Considerations for introduction of a rotavirus vaccine in Oman: rotavirus disease and 
AL-Qadisiya Journal of Vet.Med.Sci. $\quad$ Vol./12 No./1 2013

economic burden. J Infect Dis 2009, 200(Suppl 1):S248-S253.

20. Marmash RW, Dalwai AK, Szucs G, Molla AM, Pacsa AS, Al Nakib W, Albert MJ: Genotypic characterization of rotaviruses and prevalence of serotype-specific serum antibodies in children in Kuwait. Epidemiol Infect 2007, 135(8):1331-1337.

21. Eesteghamati A, Gouya M, Keshtkar A, Najafi L, Zali MR, Sanaei M, Yaghini F, El Mohamady H, Patel M, Klena JD, Teleb N: Sentinel hospital-based surveillance of rotavirus diarrhea in Iran. J Infect Dis 2009, 200(Suppl 1): S244S247.

22. Zarnani AH, Modarres S, Jadali F, Sabahi F, Moazzeni SM, Vazirian F: Role of rotaviruses in children with acute diarrhea in Tehran, Iran. J Clin Virol 2004, 29(3):189-193.

23. Benhafid M, Youbi M, Klena JD,

\section{Gentsch JR, Teleb N, Widdowson}

MA, ElAouad R: Epidemiology of rotavirus gastroenteritis among children $<5$ years of age in Morocco during 1 year of sentinel hospital surveillance, June 2006May 2007. J Infect Dis 2009, 200(Suppl 1):S70-S75.

24. Al Awaidy SA, Bawikar S, Al Busaidy S, Baqiani S, Al Abedani I, Varghesem R: Considerations for introduction of a rotavirus vaccine in Oman: rotavirus disease and economic burden. J Infect Dis 2009, 200(Suppl 1):S248-S253.

25. Wierzba TF, Abdel-Messih IA, AbuElyazeed R, Putnam SD, Kamal KA, Rozmajzl P, Ahmed SF, Fatah A, Zabedy K, Shaheen HI, Sanders J, Frenck R: Clinic-based surveillance for bacterial- and rotavirus-associated diarrhea in Egyptian children. Am J Trop Med Hyg 2006, 74(1):148-153.

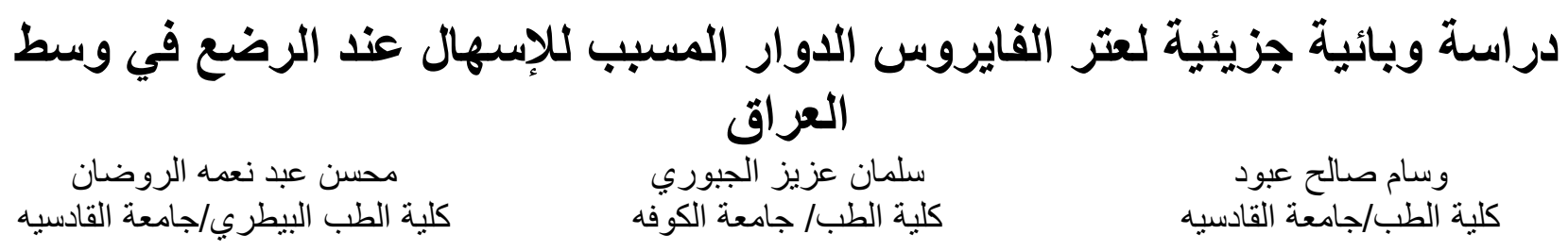

الخلاصه

ان الفايروس الدوار (روتا فايروس) المسبب للاسهال عند الاطفال يعد احد اهم مسيبات الوفيات عند الاطفال،

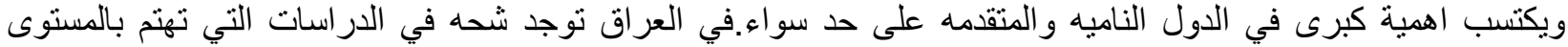

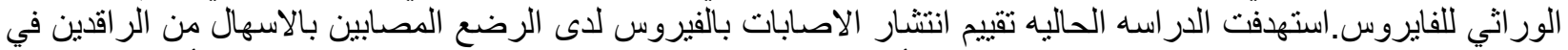

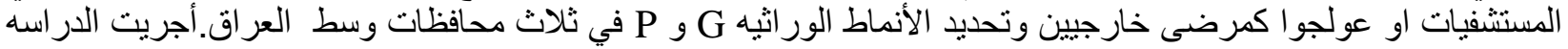

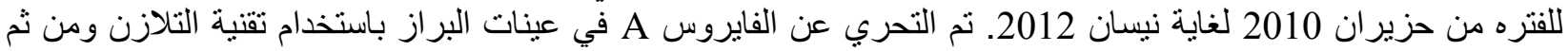

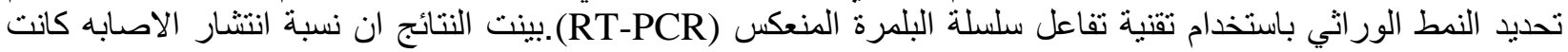

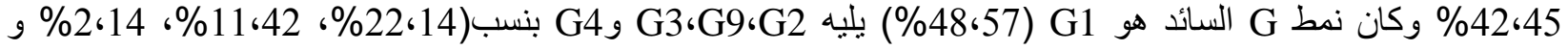

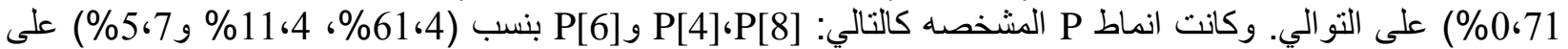

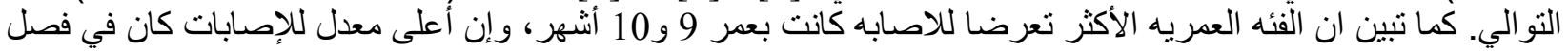

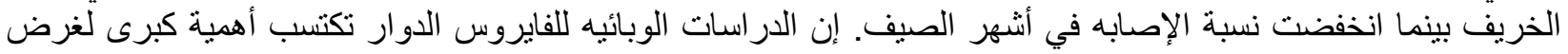

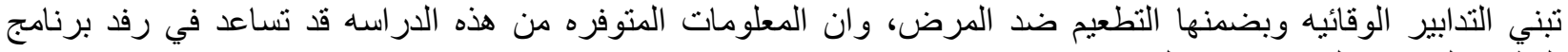
التطعيم الخاص بالفايروس في العراق. 